\title{
Glycogen Content of Rabbit Tubular Genitalia from Mating through Implantation '
}

\author{
A. T. GREGOIRE ${ }^{2}$ AND H. D. HAFS ${ }^{3}$ \\ Department of Obstetrics and Gynecology, University of Michigan \\ Medical Center, Ann Arbor, Michigan 48104
}

\begin{abstract}
Groups of five rabbits were killed at 0, 2, 4, 7, 10, 24, 48, 98, 168 and 240 hours after mating. The glycogen content of the lower half of the Fallopian tube was greater than in the upper half at each interval. Uterine and Fallopian tube levels of glycogen decreased during the interval from mating to ovulation. Both cervical and vaginal glycogen declined significantly within 24 hours after mating. Decidual uterine areas contained 1.5 and 5.0 times more glycogen on days 7 and 10 , respectively, than interdecidual areas. Castrate rabbit Fallopian tube, uterus, cervix and vagina responded with glycogen synthesis to estradiol, but not to progesterone administration.
\end{abstract}

The concentration of glycogen in the rabbit uterus is greatest in the circular muscle and in the walls of the vascular elements (Vaes and De Meyer, '57; Bo, '61). Glycogen concentration of the uterus increases during pregnancy, particularly in the mesometrial aspect of the myometrium where implantation occurs (Telfer and Hisaw, '57). Both myometrial and endometrial glycogen are elevated after administration of estrogen to immature (Zondek and Stein, '40) or mature castrate rabbits (Vaes and De Meyer, '57; Telfer and Hisaw, '57; Bo, '61) and rats (Brody and Westman, '58; Bitman, et al., '67). In contrast, progesterone administered alone (Brody and Westman, '58; Huber, '58), with estrogen (Zondek and Stein, '40; Vaes, '62; Telfer and Hisaw, '57) or with cortisone (Vaes, '62) depresses uterine glycogen.

Among published evaluations of uterine glycogen synthesis, we have been unable to find changes in glycogen concentration of the tubular genitalia during various reproductive intervals. The purpose of the present investigation was to determine changes in glycogen content of rabbit tubular genitalia from mating through implantation.

\section{MATERIALS AND METHODS}

Rabbits of mixed breeding were mated with fertile bucks and five were killed at
$0,2,4,7,10,24,48,98,168$ and 240 hours later. An additional 15 animals were castrated and rested for seven days. Then either $2 \mathrm{mg}$ progesterone, $5 \mu \mathrm{g}$ of estradiol$17 \beta$, or corn oil was injected subcutaneously, each into five rabbits daily for seven days. Among rabbits killed beyond seven hours after mating, only those with evidence of ovulation were used (ovulation points or corpora lutea). Tissues from the upper and lower Fallopian tube, uterus, cervix and vagina were removed and immediately frozen with dry ice. At the time of glycogen determination, tissue was weighed and hydrolyzed in $30 \% \mathrm{KOH}$, and glycogen was determined with anthrone reagent (Seifter, et al., '50). Results in micrograms of glycogen per $100 \mathrm{mg}$ of wet tissue weight, were subjected to analysis of variance with orthogonal contrasts.

\section{RESULTS}

Glycogen content was significantly greater $(P<0.01)$ in the lower portion than in the upper portion of the Fallopian tube at each interval after mating (table 1 , fig. 1). At four hours after copulation, glycogen in the upper and lower portions

\footnotetext{
Received April 21, '70. Accepted Sept. 4, '70.

1 This research was supported by U.S.P.H.S. research grant HD-03039.

2 Present address: Margaret Sanger Research Bureau, 17 West 16th Street, New York, N. Y.

3 Animal Reproduction Laboratory, Dairy Department, Michigan State University, East Lansing, Michigan 48823 .
} 


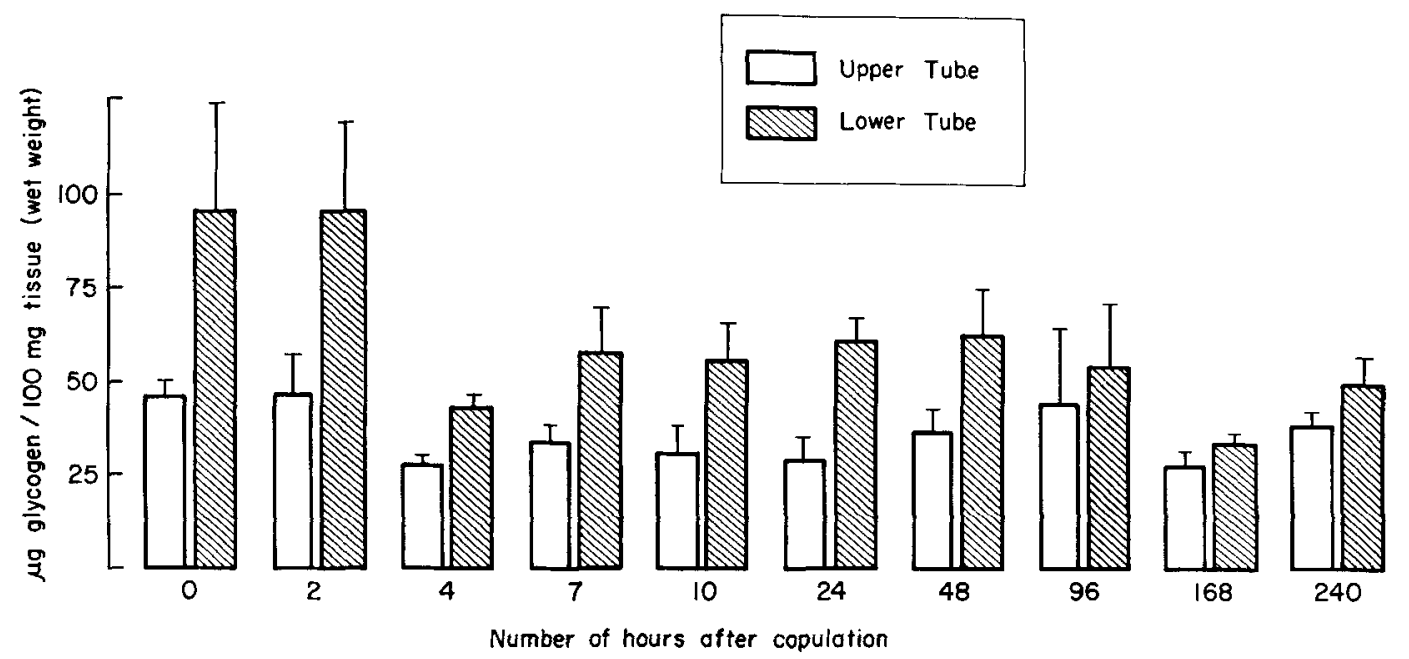

Figure 1

TABLE 1

Glycogen content of tubular genitalia from mating through implantation

\begin{tabular}{|c|c|c|c|c|c|c|}
\hline \multirow{2}{*}{$\begin{array}{l}\text { Hours } \\
\text { after } \\
\text { mating }\end{array}$} & \multicolumn{2}{|c|}{ Fallopian tube } & \multirow{2}{*}{ Uterus } & \multirow{2}{*}{$\begin{array}{l}\text { Uterine } \\
\text { decidua }\end{array}$} & \multirow{2}{*}{ Cervix } & \multirow{2}{*}{ Vagina } \\
\hline & Upper & Lower & & & & \\
\hline & \multicolumn{6}{|c|}{$\mu \mathrm{g} / 100 \mathrm{mg}$} \\
\hline 0 & $48 \pm 4^{1}$ & $97 \pm 28$ & $97 \pm 14$ & - & $60 \pm 11$ & $44 \pm 6$ \\
\hline 2 & $48 \pm 11$ & $89 \pm 27$ & $71 \pm 21$ & 一 & $53 \pm 12$ & $54 \pm 11$ \\
\hline 4 & $29 \pm 2$ & $43 \pm 4$ & $43 \pm 12$ & - & $52 \pm 6$ & $41 \pm 5$ \\
\hline 7 & $35 \pm 5$ & $58 \pm 14$ & $39 \pm 9$ & - & $63 \pm 5$ & $58 \pm 4$ \\
\hline 10 & $33 \pm 6$ & $56 \pm 11$ & $56 \pm 22$ & - & $61 \pm 15$ & $31 \pm 5$ \\
\hline 24 & $30 \pm 6$ & $63 \pm 6$ & $57 \pm 7$ & - & $37 \pm 3$ & $38 \pm 5$ \\
\hline 48 & $37 \pm 7$ & $64 \pm 11$ & $35 \pm 7$ & - & $23 \pm 3$ & $31 \pm 5$ \\
\hline 96 & $45 \pm 37$ & $55 \pm 19$ & $77 \pm 15$ & - & $33 \pm 4$ & $25 \pm 4$ \\
\hline 168 & $28 \pm 4$ & $33 \pm 3$ & $47 \pm 6$ & $74 \pm 14$ & $26 \pm 12$ & $31 \pm 8$ \\
\hline 240 & $39 \pm 7$ & $51 \pm 7$ & $43 \pm 17$ & $217 \pm 81$ & $37 \pm 9$ & $45 \pm 12$ \\
\hline
\end{tabular}

1 Each value is the mean wet weight \pm standard error for five rabbits.

of the tube was reduced to $60 \%$ and $45 \%$, respectively, from values obtained immediately after mating $(P<0.11)$. While another decrease in tubal glycogen occurred near the time of implantation seven days after copulation, it was not signifcant. During the course of the study, 15 additional rabbits failed to ovulate after mating, and the glycogen content of the upper and lower tubal tissue of these did not differ significantly; i.e., 62 and $63 \mu \mathrm{g}$ of glycogen per $100 \mathrm{mg}$ of upper and lower tubal tissue, respectively.

Glycogen content of uterine tissue was significantly greater $(\mathrm{P}<0.01)$ in rabbits immediately after mating than the average of the subsequent intervals (table 1). Reduction of uterine glycogen apparently was complete by four hours after mating, and fluctuations thereafter were not significant. At seven and ten days after mating, glycogen in the uterine implantation sites was 1.5 and 5.0 times greater, respectively, than that in the interdecidual uterine tissue, respectively $(P<0.10)$.

The glycogen content of the cervix varied little either before or after ovulation, but levels after ovulation were only about $50 \%$ of those before ovulation $(\mathrm{P}<.001)$. Vaginal glycogen also decreased $(\mathrm{P}<.05)$ from before to after ovulation, but the major reduction occurred near ovulation between seven and ten hours after mating.

The amount of glycogen in tissues from the castrate controls was always less than 
that in comparable tissucs from intact rabbit (table 2). Administration of estradiol to castrates resulted in a significant increase in glycogen concentration in each segment of the tubular genitalia (fig. 2). Relative to castrate controls, estradiol increased glycogen content of cervical tissue about five-fold, while comparable increments in all other tissues were about twofold. Glycogen in the Fallopian tube, uterus and vagina of rabbits treated with estradiol (table 2) approached levels observed in intact rabbits (table 1), while the cervical glycogen was considerably

TABLE 2

Glycogen content of tubular genitalia in castrate rabbits following injections of estradiol or progesterone

\begin{tabular}{llcc}
\hline \multirow{2}{*}{ Organ } & \multicolumn{3}{c}{ Steroid injected } \\
\cline { 2 - 4 } & Control & Estradiol & Progesterone \\
\hline Fallopian tube & & $\mu 9 / 100 \mathrm{mg}$ \\
Upper & $28 \pm 7^{1}$ & $46 \pm 11$ & $30 \pm 5$ \\
Lower & $23 \pm 3$ & $61 \pm 19$ & $28 \pm 3$ \\
Uterus & $31 \pm 11$ & $57 \pm 16$ & $21 \pm 2$ \\
Cervix & $16 \pm 1$ & $89 \pm 32$ & $21 \pm 4$ \\
Vagina & $22 \pm 3$ & $36 \pm 12$ & $31 \pm 5$ \\
\hline 1 Each value is the mean wet weight \pm standard \\
error for five rabbits.
\end{tabular}

greater in rabbits injected with estradiol. Progesterone administration failed to alter significantly glycogen levels relative to those obtained from castrates injected with corn oil.

\section{DISCUSSION}

The glycogen in human Fallopian tubes, localized mostly in the ciliated cells, exhibits cyclic changes in concentration and localization during the menstrual cycle (Fredricsson, '59a). Administration of estrogen to rabbits results in granular glycogen deposition in the basal portion of the tubal epithelial cells, and is limited mostly to the ciliated cells (Fredricsson, '59b; LeBeux, '68). We found tubal glycogen decreased within four hours after mating in rabbits, possibly due to rapidly increasing levels of $20 a$-hydroxy-pregn-4en-3-one (Hilliard et al., '64).

The tubal glycogen may be (1) a source of the lactic acid, present in rabbit tubal fluid after mating (Mastroianni et al., '61); (2) a source of energy for ciliated cells; or (3) a nutrient for the developing ova. Glycogen synthesis has been demonstrated in developing mouse ova, and the precursors of glycogen synthesis may be present

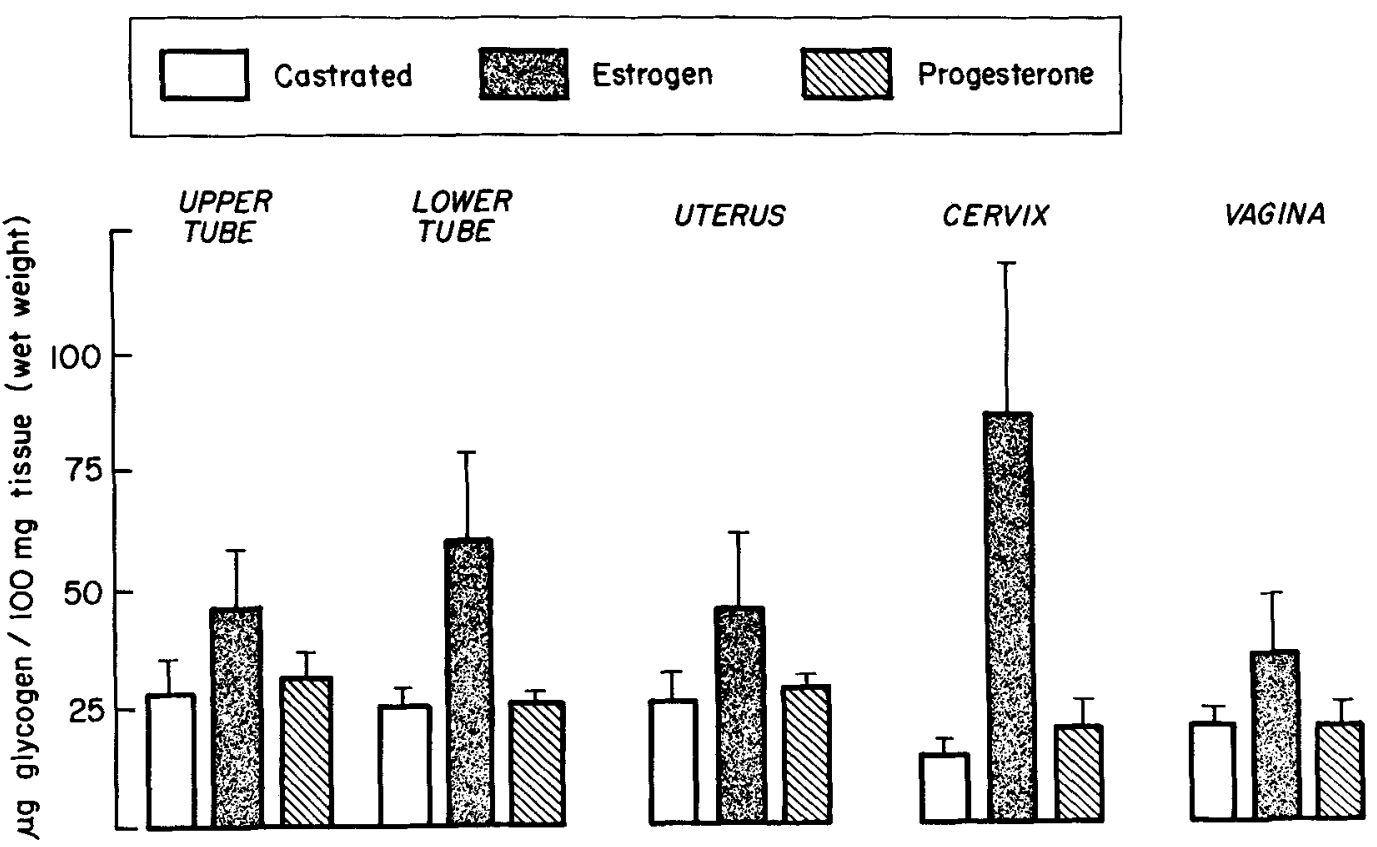

Figure 2 
in tubal fluid or the tube itself (Stern and Biggers, '68). The malto-oligosaccharides, products of glycogen metabolism, occur in all portions of the rabbit genital tract and increase in response to estrogen (Gregoire and Gibbon, '65).

Human endometrial glycogen is maximum after ovulation (Hughes, '45), but rat (Boettiger, '46) and hamster (Gregoire and Guinness, '68) uterine glycogen is greatest before ovulation. Rabbit uterine glycogen decreases four hours after mating, but the amount of glycogen in rabbit uterine tissue is less than that in either hamsters (Gregoire and Guinness, '68) or rats during pro-estrus (Kostyo, '57).

Rat decidual glycogen appears on day 5 and attains maximum concentration nine days after mating (Christie, '66), while hamster decidual glycogen is considerably greater than that of interdecidual tissue on day 6 and further increases occur by days 7 and 8 after mating (Orsini, '63; Gregoire and Richardson, '70). In confirmation of the comparatively low glycogen levels reported for rabbits (Lutwak-Mann, '54), even the highest glycogen levels in rabbit decidual tissue at seven and ten days after mating are less than those reported for other species.

Human ectocervical glycogen is constant and limited to the squamous epithelial layer (Gregoire and Ledger, '69; Fineberg and Cohen, '68), while hamster cervical glycogen increases the day preceding ovulation (Gregoire and Guinness, '68). Maximal glycogen synthesis in the cervix of castrate rats occurs with $25 \mu \mathrm{g}$ of estradiol, and cervical levels of glycogen are greater than those in the vagina but less than those in the uterus (Gregoire et al., '67). Rabbit cervical glycogen decreased before implantation, but we found neither the large concentration as in humans nor the preovulatory rise as in hamsters.

The amount of estrogen administered and vaginal glycogen deposition are positively related in prepubertal rats (Wrenn et al., '68) and hamsters (Gregoire and Richardson, ' $70 \mathrm{~b}$ ). The increased uterine glycogen in castrate rabbits in response to estradiol administration confirms previous reports (Bitman et al., '67; Telfer and Hisaw, '57). The amount of glycogen synthesis in rabbits, however, is not as great as that obtained in hamsters following estrogen stimulation. Nor are changes in rabbit vaginal glycogen after injections of estradiol as dramatic as those obtained with small amounts of topically applied estrogen in the rat vagina.

Therefore, while glycogen synthesis is generally a function of estrogen, it varies markedly among reproductive tissues and among species. The glycogen synthesis response to estrogen in a particular species may be related to the number of estrogen binding sites (Jensen et al., '68), or to the ability of estrogen to convert the dependent form of glycogen synthetase (Williams and Provine, '66).

\section{LITERATURE CITED}

Bitman, J., H. C. Cecil, J. R. Wood and T. R. Wrenn 1967 Comparison of oestrogen-induced glycogenesis in the uterus of the rat, rabbit and sheep. Acta Endocrin., 54: 505-513.

Bo, W. J. 1961 The effect of hormone treatment on the phosphorylase activity of the rabbit uterus. J. Histochem. Cytochem., 9: 430433.

Boettiger, E. G. 1946 Changes in the glycogen and water content of the rat uterus. J. Cell. and Comp. Physiol., 27: 9-14.

Brody, S., and A. Westman 1958 Effects of oestradiol and progesterone on the glycogen content of the rabbit uterus. Acta Endocrin., 28: $39-46$.

Christie, G. A. 1966 Implantation of the rat embryo: Glycogen and alkaline phosphatases. J. Reprod. Fertil., 12: 279-294.

Feinberg, R., and R. B. Cohen 1968 Enzymes of glycogen metabolism in the squamous epithelium of the cervix: A histochemical study. Obstet. Gynecol., 31; 608-616.

Fredricsson, B. 1959a Histochemical observations on the epithelium of human fallopian tubes. Acta Obstet. Gynecol. Scand., 38: 109134.

1959b Proliferation of rabbit oviduct epithelium after estrogenic stimulation, with reference to the relationship between ciliated and secretory cells. Acta Morph. Neerl. Scand., 2: 193-202.

Gregoire, A. T., and R. Gibbon 1965 Glucosyl oligosaccharides of the rabbit genital tract: Effects of ovarian hormone administration. Int. J. Fertil., 10: 151-155.

Gregoire, A. T., and B. J. Guinness 1968 Cyclic and pre-ovulatory changes in the glycogen content of the female hamster genital tract. J. Reprod. Fertil., 17: 427-432.

Gregoire, A. T., and W. J. Ledger 1969 The glycogen content of human ectocervical tissue of females receiving steroid contraceptive therapy. Fertil. Steril., 20: 91-97.

Gregoire, A. T., H. Ramsey and A. Adams 1967 The effect of various doses of oestradiol $17-\beta$ 
on glycogen deposition in the rat uterus, cervix and vagina. J. Reprod. Fertil., 14: 231-234.

Gregoire, A. T., and D. W. Richardson 1970a The glycogen content of the early pregnant female hamster genital tract, the fertile conceptus and artificially induced deciduomata. J. Endocrin., 46: 9-14.

1970b Glycogen and water responses to estrogen in the hamster reproductive tract. Manuscript submitted for publication.

Hilliard, J., J. N. Hayward and S. H. Sawyer 1964 Postcoital patterns of secretion of pituitary gonadotropin and ovarian progestin in the rabbit. Endocrinology, 75: 957-963.

Huber, A. 1958 Utber den Einfluss der Ovarialhormone auf die Glykogenbildung. Beobachtungen am Kaninchenuterus. Gynaecologia (Basel), 146: 111-116.

Hughes, E. C. 1945 Relationship of glycogen to problems of sterility and ovular life. Am. J. Obstet. Gynecol., 49: 10-18.

Jensen, E. V., T. Suzuki, T. Kawashima, W. E. Stumpf, P. W. Jungblut and E. R. DeSombre 1968 A two-step mechanism for the interaction of estradiol with rat uterus. Proc. Nat. Acad, Sci., 59: 632-638.

Kostyo, J. L. 1957 A study of the glycogen levels of the rat uterus and certain skeletal muscles during pregnancy. Endocrinology, 60: 33-37.

LeBeux, Y. 1968 Presence de corpuscles glycogeniques dans la cellule ciliee de l'epithelium tubaire de la lapine. J. Microscopie, $7: 445-450$.

Lutwak-Mann, C. 1954 Some properties of the rabbit blastocyst. J. Embryol. Exp. Morph., 2: $1-13$.
Mastroianni, L., Jr., and R. C. Wallach 1961 Effect of ovulation and early gestation on ovi. duct secretions in the rabbit. Am. J. Physiol., 200: 815-818.

Orsini, M. W. 1963 Morphological evidence on the intrauterine career of the ovum. In: Delayed Implantation. A. C. Enders, ed. University of Chicago Press, Chicago, pp. 155-169.

Seifter, S., S. Dayton, B. Novic and E. Muntwyler 1950 The estimation of glycogen with the anthrone reagent. Arch. Biochem., 25: 191-200.

Stern, S., and J. D. Biggers 1968 Enzymatic estimation of glycogen in the cleaving mouse embryo. J. Exp. Zool., 168: 61-66.

Telfer, M. A., and F. L. Hisaw, Jr. 1957 Biochemical responses of the rabbit endometrium and myometrium to oestradiol and progesterone. Acta Endocrin., 25: 390-404.

Vaes, G. 1962 The effect of corticotrophin and cortisone on uterine glycogen in the rabbit. Acta Endocrin., 39: 513-517.

Vaes, G., and R. De Meyer 1957 Etude histochimique du glycogene uterin chez la lapine; ses variations au cours du diabete alloxanique et sous l'action de la cortisone. Ann. d'Endocrin., 18: 828-840.

Williams, H. E., and H. T. Provine 1966 Effects of estradiol on glycogen synthetase in the rat uterus. Endocrinology, 78: 786-790.

Wrenn, T. R., J. Bitman and J. R. Wood 1968 Influence of local estrogen administration on vaginal glycogen. Endocrinology, 82: 62-68.

Zondek, B., and L. Stein 1940 Glycogen content of the human uterine mucosa glycopenia uteri. Endocrinology, 27: 395-399. 